\title{
Identity and Geopolitics: Ukraine's Grappling with Imperial Legacies
}

\author{
JACOBUS DELWAIDE
}

\section{D}

URING HIS 18 MARCH 2014 KREMLIN SPEECH celebrating Russia's invasion of Ukraine and annexation of Crimea, Vladimir Putin declared, "Kiev is the mother of Russian cities. Ancient Rus is our common source and we cannot live without each other." Russia's strongman was not alone in this conviction: the view of Ukraine as Russia's heartland, Andrew Wilson noted, remains central to most Russians' "understanding of their origins as a nation."2 Touting Kyiv as "the mother city of Russia" 3 and Ukraine as a largely Russian land is often taken for granted - including in the West where Ukraine can be pictured as "the very steppes" and "the very forests that birthed the Russian nation."4

On 1 March 2014 the Federation Council, Russia's upper house of parliament, had unanimously authorized President Putin to resort to armed intervention in Ukraine in order to protect "citizens and compatriots." Already in the late 1990s, Russian lawmakers had struggled to define "compatriot"; they "finally decided that pretty much anyone can be a Russian compatriot abroad, as long as they 'act Russian and love Russia." "Putin specified that not only "all native Russians," but also "the Russian-speaking people living in Ukraine" deserved Russian protection. ${ }^{7}$ The extraordinary carte blanche given by the Russian parliament thus relied on strikingly elastic concepts. ${ }^{8}$ Consequently, "who an individual is according to law or his own preferences" did not matter in the least: "The fact that he speaks Russian makes him a Volksgenosse requiring Russian protection, which is to say invasion." With no evidence of human rights violations in Crimea, and with the exceedingly vague claim to protect "Russians," the bar for armed intervention and the violation of sovereignty was set dangerously low - a profound challenge to the international order. ${ }^{10}$

Heaping the "ethnic Russians and the Russian language"11 together, Russia implicitly laid claim to a large swath of Ukraine - in Putin's terminology, "Novorossiya,"12 stretching all the way to the Moldovan and Romanian borders. Putin had already hinted that Ukraine "isn't a state," and that a significant part of its territory "was given" to it by Russia. ${ }^{13}$ The border between Russia and Ukraine 
was, somehow, the result of a staggeringly immense, ancient but still ongoing conspiracy:

The intention to split Russia and Ukraine, to separate what is essentially a single nation in many ways, has been an issue of international politics for centuries.

...Unfortunately, this policy of division, of pulling apart and weakening both parts of a single nation continues. ${ }^{14}$

Thus Ukraine was perceived as part “of either Russia, or Russia's Huntingtonian zone of civilisational hegemony." 15

Yet, how well founded are such encompassing, metairredentist claims? The following analysis clusters around three highly contentious issue areas: national origins, language, and state violence - specifically the treatment of Ukrainian compatriots in Soviet times. All three issue areas are being illuminated, nowadays, thankfully, by an effervescent scholarly literature.

\section{KYIV AND Muscovy}

Russian historic claims to Ukraine are not at all obvious. The term Kyivan Rus' for the medieval (late ninth to mid-thirteenth century) realm centered on Kyiv "comes from imperial Russian historiography," and had the function of distinguishing the Kyivan from the Muscovite period in the imperial Russian narrative. ${ }^{16}$ After World War II, the notion of an "Old Rus' nationality" gained particular momentum in Soviet historiography: it "served, inter alia, to establish Russia's claim to the historical legacy of Kyivan Rus' and therefore survived the demise of Soviet historiography," remaining "quite popular in Russia today."17

During the late thirteenth and early fourteenth centuries, with the rise of the Grand Duchy of Lithuania, the Rus' elites submitted to the Lithuanian princes, "while the Mongols took over the eastern and northern parts of the former Kyivan realm." ${ }^{\prime 18}$ Muscovy's emergence as a state during the late fifteenth century and its expansion and eventual emancipation from Mongol control led to a resurgence of interest in the Kyivan heritage: "There was hardly a better way for the Muscovite elites to dissociate themselves from their recent Tatar past than to stress the Roman, Byzantine and, inevitably, Kyivan roots of the Muscovite dynasty." 19 As a result, "Kiev is more usually associated in people's minds with 'ancient Russia' than with medieval Lithuania" and "is frequently billed as 'Russia's birthplace,", a myth Norman Davies emphatically rejects: "One cannot judge medieval events by the teleological standards of a Russia that had yet to be created." Davies emphasizes: "Early Rus' was a world without Moscow, and, more importantly, without the self-centred theories of history which the Muscovites would later 
invent and impose." ${ }^{20}$ Moscow did not control Kyiv "for nearly half a millennium after the destruction of that medieval state. For most of the time Kiev was ruled from Vilnius and Warsaw." ${ }^{21}$ Meanwhile, "The concept of the Rus' Land, which the Rus' chroniclers originally applied to Kyiv and the surrounding area," was appropriated by Muscovy "to denote all its new possessions, including Novgorod, Pskov, and even Kazan," conquered from the Tatars. ${ }^{22}$

Generally, Serhii Plokhy affirms, the national paradigm — including the Ukrainian paradigm - is "not very helpful" in the search for "the origins of East Slavic identities." Rus' identity was "always in flux and highly fragmented."23

\section{POLAND AND UKRAINE}

While it is often asserted that Russia and Ukraine share a "largely common history," ${ }^{24}$ historians point to the depth of the Polish-Ukrainian nexus, ${ }^{25}$ and dismiss the blending of Ukraine's history with Russia's as shortsighted:

To consider Ukraine's normal condition to be that it is part of Russia is a major misreading of history, one that implies that its present independence is an anomaly....

...Before 1648, virtually all Ukrainians lived within the Polish-Lithuanian Commonwealth. ${ }^{26}$

And even after 1648, the Polish nobility remained the dominant group in the area for two more centuries. Indeed, "Russians never altogether lost the fear that Poles were on the alert to claim Ukrainians and Belorussians for an alternative national project. For that reason the tsarist regime abolished distinct Ukrainian institutions and referred to the geographical area as 'Little Russia." ${ }_{27}$

Poland's sudden reemergence in November 1918, thanks to the collapse of "all three of the partitioning empires"-German, Habsburg, and tsarist Russian — "was much resented in Moscow and Berlin." ${ }^{28}$ The 1920 Piłsudski-Petliura invasion of Bolshevik-controlled Ukraine sealed the "alliance between socialism and the ghost of imperial Russia," Geoffrey Hosking writes. "Historically the Poles were national enemies who had for centuries disputed the western regions of what Russians considered to be their own territory. Resisting them was the duty of every patriotic Russian," the Reds now argued, successfully fusing "revolutionary élan with Russian nationalism." 29

By 1930, under Stalin, "a persistent connection between language and terror had established itself in the western republics" where "issues of cultural hegemony were more sensitive," Terry Martin observes. 
Polish culture. Therefore, any perceived rejection of Russian culture was apprehended as a move toward Polish culture, and given the hostility between the Soviet Union and Poland, the charge quickly became ideological. ${ }^{30}$

During "the first major actions against nationalities" in 1932-1933, "the borderlands of the West were 'cleansed' - the Soviets' word - of allegedly dangerous and traitorous Poles and Germans." 31 The Poles were to be "completely destroyed," an NKVD official stated. Stalin egged on: "Keep on digging up and cleaning out this Polish filth." Some 111,000 people were shot. ${ }^{32}$

Ethnic Poles, Timothy Snyder remarks, "suffered more than any other group within the Soviet Union during the Great Terror."33 When the Nazi-Soviet Pact secretly partitioned Poland again, Molotov commented: "One swift blow to Poland, first by the German army, and then by the Red Army, and nothing was left of this ugly offspring of the Versailles Treaty." After the Soviets invaded eastern Poland (western Belarus and western Ukraine), "over 300,000 Poles, mostly women and children" were deported, thousands dying as a result. Educated Poles were imprisoned, "including approximately 22,000 army officers." Stalin and Beria ordered their execution, resulting notably in the infamous June 1940 Katyn massacre, "denied by the Soviet regime until the very end of its existence." 34

Clearly Poland continued to loom large, more than a century and a half after the initial partitions. Hence, "it is impossible to understand today's Ukraine if one sees it as a province of Russia." 35 Only the outcome of World War II would herald "the definitive end to the long historical struggle with the Poles." But in the longer run this end would also "undermine a key reason for Ukrainian solidarity with Moscow."36

\section{EMPIRE AND NATION}

Russians, Vera Tolz writes, "failed to distinguish between national and imperial" and started "the process of inventing a truly national tradition" only around the onset of the twenty-first century, "something which most other European nations have been successfully doing since the nineteenth century." ${ }^{37}$ Russia, Richard Pipes remarks, has yet to come to terms with its empire's historical "obsession with military power and territorial expansion," an expansion fueled by patrimonial autocracy and environmental poverty, a rambling empire whose maintenance, in turn, fed the need for autocracy. ${ }^{38}$ Thus, a vicious self-reinforcing circle of autocracy and expansion was set in motion. Or the other way around, as some authors suggest: "The tsars' need to pay for institutional modernization engendered a degree of social rigidity unknown to Muscovy and eventually helped to sink Russia deeper into economic backwardness." ${ }^{39}$ Hosking, too, argues that "autocracy and backwardness were symptoms and not causes: both were gener- 
ated by the way in which the building and maintaining of empire obstructed the formation of a nation." Indeed,

\begin{abstract}
in Russia state-building obstructed nation-building. The effort required to mobilize revenues and raise armies for the needs of the empire entailed the subjection of virtually the whole population, but especially the Russians, to the demands of state service, and thus enfeebled the creation of the community associations which commonly provide the basis for the civic sense of nationhood. ${ }^{40}$
\end{abstract}

Meanwhile the way in which Muscovy initially developed and rose left traces in its genetic code: "long habituation to Mongol rule led Muscovy to adopt a number of important elements of its political culture and thinking, as well as its social and economic practices," notably "the concept that all the land belonged to the ruler," practices "often shared with lands as distant as China." As a result, "Northeastern Rus' emerged from the period of Mongol rule strong and united but also very different from those parts of the Rus' that did not experience the long rule of the khans." ${ }^{41}$ From Ivan IV through Peter I, Stéphane Courtois concludes, there is a clear linkage between absolute power and "the ever greater subjection of the people and the elites to a dictatorial and terrorist state." ${ }^{\prime 2}$

Ukraine, like so many nations, had to be imagined, most notably by the grand "synthesis" in Mykhailo Hrushevs'kyi's Istoriia Ukraïny-Rusy (History of Ukraine-Rus'). ${ }^{43}$ Andreas Kappeler highlights the small national movement and the role played in it by "Poles, Russians, Jews and Germans." ${ }^{44}$ Serhii Plokhy points to the impact of Cossack myth fueled by the post-Napoleonic Istoriia Rusov (History of the Rus'), influencing notably Taras Shevchenko and Hrushevs'kyi, and the role of "highly placed imperial officials" in reading and disseminating this text. ${ }^{45}$ As a result of World War II, "Ukrainian ethnic territories previously held by Poland, Czechoslovakia, and Romania" were joined "with the Soviet Ukraine" under Stalin's aegis. ${ }^{46}$ As the Soviet Union disintegrated, Ukraine had to be put back on the (mental) maps. Also in the West, scholars had "for many decades" adopted an "all-Union approach—often including a specifically Russian approach - to the study of the Soviet Union." ${ }^{47}$ Russia, understandably, experienced the greatest difficulties after 1991. Amid "the shaping and reshaping of identities" in Russia and Ukraine, "the perception of history" became "a chief battleground in the struggle over identity." ${ }^{48}$ For Russia, Tolz observed a decade after the Soviet Union's disintegration, reconsidering its past and present relationship with Ukraine remains "arguably the most problematic part of the construction of a new national identity," a construction that will "take decades."49

For "the large majority of patriots, chauvinistic nationalists, or simply deeply insecure Soviet citizens," an independent Ukraine was "a monster, an illegitimate bastard that ought to be led back to the family dinner table as soon as possible." 
"For openly or latently neo-imperial Russians," Ukraine constitutes "the most important "loss." ${ }^{51}$ Russian commentators highlight "the deeply held belief in Russia that Ukraine is a special and exceptionally important partner in historical, cultural, and other respects." ${ }^{52}$ Russian elites, scholars concur, still have plenty of homework to do with regard to the imperial past, notably their "striking ignorance of Ukraine" 53 and their "huge emotional investment" in "the belief that Ukraine cannot "tear itself away' from Russia." "54 "During the past 20 years," an observer remarked in 2014, "it is difficult to think of any Russian leader-not just Mr. Putin - who has found it psychologically and politically comfortable to think of Ukraine in its 1991 borders as a legitimate, independent state." ${ }^{55}$ Even Yeltsin, famously present at the dissolution, saw Russia's neighbors "as little more than vassal states." ${ }^{\prime \prime 6}$ And "people around Yeltsin" believed the CIS would allow Russia "to maintain its de facto control and influence over the post-Soviet territory so that the republics would de jure become independent states, but their independence would not be complete." ${ }^{57}$ Wilson notes, "the vast majority of Russian politicians and academics have yet to engage seriously with the reality of Ukraine's separate existence." Even among those "who have addressed the question in depth, attitudes are still dismissive." 58 From a Russian perspective, Ukraine is not "serious," and the Ukrainian language is merely "a dialect of Russian" or even "a Southern pronunciation of the Russian language." 59 The roots of this attitude can in part be traced to the numerical weight of ethnic Russians within the empire - roughly half of the population, in contrast with Austrian Germans who formed only "a small minority in their own empire." ${ }^{60}$ The myth of a common origin, discussed (and dismissed) above, also plays a major role, as does the widespread conviction (tackled below) that until 1991 relations had been "largely harmonious."

\section{PATTERNS OF COLONIZATION}

Scholars generally agree that "the relations of control, inequality, and hierarchy between the centre and the periphery qualified the USSR as an empire." 62 Kappeler, however, cannot discern either the "spatial, cultural and racial distance" or "the juridical discrimination of Ukrainians vis-à-vis the Russians" to speak of Ukraine as a "classical colony of the Russian empire." ${ }^{63}$ Wilson concurs: Ukraine "was never a classic colony." ${ }^{64}$ David Laitin distinguishes three patterns of peripheral incorporation in the tsarist and Soviet empires: a "classic" colonial model, exemplified by Kazakhstan, "where elite ambitions could only be fulfilled as subalterns under Russian surveillance within the titular republic"; an "integral" model, exemplified by the Baltic states, where "mobility prospects were partly blocked but rather rapid within the republic"; and a "most favored lord" model, exemplified by Ukraine, where elites had "rights and privileges equal to those of similar status and education in the political center." ${ }^{65}$ Laitin underscores Ukraine's linguistic proximity and the similarity in levels of development, which reduced 
the difficulties and costs of integration at the center: by the late nineteenth century, literacy levels were comparable in Russia and Ukraine (29.6 and 27.9 percent, respectively), yet far higher in Estonia (96.2), and far lower in Kazakhstan (8.1). ${ }^{66}$ Other authors plainly describe Ukraine as a Russian colony, comparable, for instance, to Ireland under British rule ${ }^{67}$ For all practical purposes, the Soviet Union, like its tsarist predecessor, was an empire, and the effect of imperial rule in Ukraine, particularly after the rollback of the Ukrainization drive, was akin to colonization. ${ }^{68}$ The Soviet Union "died the death of an empire"; its end "is best understood in the context of the disintegration of other major European empires in the 20th century starting with the Hapsburgs, the Ottomans, the British, French, Portuguese. $" 69$

The tsarist empire made no attempt to assimilate the Ukrainian peasant masses, already considered to be Russian ("Little Russian"), and merely sought to prevent "nationalists and radicals from reaching out to the villages." empire "did its best to prevent the emergence of a printed Ukrainian literary culture." ${ }^{\prime \prime}$ Serious attempts to Russify the Romanovs' subjects came only under the last two tsars. ${ }^{72}$ While belated, tsarist oppression came to focus particularly on Ukraine. ${ }^{73}$ Habsburg-controlled Galicia with its capital Lemberg (Lviv) famously offered a cultural breather. Annexed by the Habsburgs during the first partition of the Polish-Lithuanian Commonwealth in 1772 and ruled by them for almost a century and a half, Galicia enjoyed some basic civic freedoms (including equal status for the Uniate, or Greek Catholic Church) unknown in the Russian empire. Galicia, an eastern Ukrainian leader remarked in his memoirs, was "a true 'Piedmont' of the Ukraine because prior to 1906 a Ukrainian press, scholarship and national life could develop only there." ${ }^{\prime 4}$ The Habsburgs, "fearing both Polish nationalism and Russian expansionism," fostered Ukrainian nationalism "through schools, societies, and paramilitary scouting organizations," a nationalism that would remain "remarkably durable" in the region. ${ }^{75}$

Concern (particularly Lenin's) about "Great-Russian chauvinism" lay at the root of the Soviet nationalities policy of korenizatsiia (nativization), which created "the affirmative action empire," the title of Terry Martin's monumental study. A key motivation behind the nationalities policy, Martin makes clear, was

\footnotetext{
"the cruel lesson of 1919."...Mass peasant uprisings led by Petliura combined with Denikin's White army to drive the Bolsheviks out of Ukraine for a second time. The lesson, reiterated...time and again, with uncharacteristic candor, was that their own chauvinistic behavior had provoked this mass peasant nationalist uprising. ${ }^{76}$
}

The hostility of the city to all things Ukrainian had caused peasants to rebel against the "foreigners" - the Communists. The distance between country and city had to be overcome: peasants should be able to feel at home in the cities. In Ukraine, korenizatsiia was applied with particular intensity. During the 1920s, moreover, 
"Soviet Ukraine was seen as a twentieth-century Piedmont that would serve as the center to unite, first culturally and then politically, the divided Ukrainian populations of Poland, Czechoslovakia, and Romania." 77 The Soviet nationalities policy brought about a short-lived Ukrainian cultural spring. A dramatic rise in literacy was accompanied by a "print revolution," and "by the late 1920s, the great majority of books, journals, and newspapers were in Ukrainian." ${ }^{78}$ Martin frames the key paradox of Soviet Ukrainization as follows:

In Ukraine, there was both exceptionally strong support for and resistance to linguistic Ukrainization. Moreover, both support and resistance came from within the party. Nowhere else did the higher party leadership more consistently or more aggressively attempt to implement linguistic korenizatsiia. On the other hand, nowhere else did it face such entrenched opposition. ${ }^{79}$

This opposition was centered in the "entrenched urban Russian and russified proletariat" and in the "strong russified Old Bolshevik cadre." By 1932 "the project of comprehensive linguistic Ukrainization had failed." Subsequently, "the socialist offensive brought increased centralization and therefore a greater penetration of the Russian language as well as a new wave of ideological hostility to Ukrainization." Thus the terror, according to Martin, was "a response to the political and not the social consequences of Ukrainization."

Indeed the "Piedmont Principle" had turned into a double-edged sword also cutting eastward, affecting Ukrainians living in Russia-millions since the 1925 border compromise, a fact conveniently forgotten in Russian claims on parts of Ukraine. In western Russia, "regions increasingly appealed to Ukraine for help in Ukrainization." "On 14 and 15 December 1932, the Politburo passed two secret decrees that reversed, but only in the Ukrainian case, the official nationality policies decided upon in 1923," declaring that those policies had spurred nationalistic feelings instead of absorbing them. ${ }^{82}$ The wave of terror accompanying the socialist offensive "targeted Ukrainian nationalists but not Great-Russian chauvinists." 83

"Ukraine occupied the central role in the evolution of Soviet nationalities policy throughout the Stalinist period," Martin emphasizes. "The Ukrainian question took over the role played by the Polish question in prerevolutionary Russia." Partly this was "a matter of sheer size," notably the number of Ukrainians within the Soviet Union, including those within the Russian Federation. Ukraine's location along "the crucial Soviet-Polish border" and its agricultural and industrial significance also mattered greatly. ${ }^{84}$ Ukraine was "the most sensitive republic for the operation of the Soviet Union as a multiethnic state," Hosking adds. Ukraine contained "many of the Soviet Union's key industrial projects" and was its "breadbasket, the arena for the struggle to feed the cities and the armed forces in the face of peasant defiance," a defiance that was particularly pronounced 
in Ukraine where it was sometimes linked with nationalist demands. ${ }^{85}$ Internal discussions within the Communist Party of Ukraine were replete with references to the particular nature of Ukrainian villages, the party's difficulties in gaining a secure foothold there, and the role of nationalism and "chauvinism."

\section{FAMINE}

"The most important thing right now is Ukraine," Stalin wrote in August 1932, expressing fear of Polish infiltration and perceiving a real risk the Soviet Union might "lose" Ukraine. ${ }^{87}$ This, Andrea Graziosi concludes, fueled his eagerness to settle both the peasant question and the national question there. ${ }^{88}$ Stalin, Martin writes, "was now singling out Ukraine itself as a 'unique' national republic whose party had been infiltrated by Ukrainian nationalists (Petliurites) who were in turn serving Pilsudski's ongoing project of exploiting Ukrainian nationalism to annex Ukraine." ${ }^{" 99}$ However, by then Poland no longer possessed the economic or military wherewithal for such designs: Poland had consented to a nonaggression pact with the Soviet Union, initialed in January 1932 and signed in July 1932, thus accepting the status quo, giving Stalin "far more room for maneuver in his western borderlands," and leaving the Ukrainian peasants at his mercy. ${ }^{90}$

The 14 December 1932 Politburo decree "articulated the national interpretation of the 1932 grain requisitions crisis. Ukraine and the North Caucasus were singled out for their lack of vigilance," and in both areas - the Soviet Union's two most important grain-growing regions - "the Politburo blamed this lack of vigilance on Ukrainization." Martin concludes,

The 1932-1933 terror campaign consisted of both a grain requisitions terror, whose primary target was the peasantry, both Russian and non-Russian, and a nationalities terror, whose primary target was Ukraine and subsequently Belorussia.... The famine was not an intentional act of genocide specifically targeting the Ukrainian nation. It is equally false, however, to assert that nationality played no role whatsoever in the famine. ${ }^{91}$

Hence one of the prominent scholars of Soviet nationalities policy does not classify the famine as genocide, yet he does link it to nationality and the nationalities terror. In his contribution to the famed Black Book of Communism, Nicholas Werth, while acknowledging Stalin's "Ukrainophobia" and depicting the Ukrainian peasantry as "the principal victim" of the famine, points to other areas like Kazakhstan that were also severely affected. Werth interprets the famine as "the ultimate episode" of the confrontation, started in 1918-1922, "between the Bolshevik state and the peasantry." ${ }^{\prime 2}$ Wilson concurs with this reading, yet reminds us that the famine "all but destroyed the social and cultural reservoir 
of Ukrainian identity in the countryside," weakening nationalism and isolating "even more" the intelligentsia, 80 percent of which was eliminated by the purges that "hit Ukraine particularly hard." 93

A decade later, however, "taking into account new evidence and new arguments," Werth came to the conclusion that the Ukrainian famine has to be interpreted as genocide. ${ }^{94}$ Other scholars also see the famine as an unambiguous instance of genocide. While the famines did have a "pan-Soviet" quality, in Ukraine the countryside was targeted "with the full awareness that the village represented the nation's spine." 95 As opposed to smaller nations that were to suffer full-scale deportation, Ukrainians could not be erased by starvation and deportation: "there were quite simply too many Ukrainians to deport them all, and too much fertile agricultural land in the Ukrainian steppe that needed able farmhands." ${ }^{96}$ Estimates place the number of victims of the Ukrainian famine of 1932-1933 anywhere "between four or five million to seven million, or indeed more," amounting to "between a fifth and a quarter of the entire Ukrainian rural population." Snyder assumes that "no fewer than 3.3 million Soviet citizens died in Soviet Ukraine of starvation and hunger-related disease," while "about the same number of Ukrainians (by nationality) died in the Soviet Union as a whole." In addition, "hundreds of thousands of orphans would grow up to be Soviet citizens but not Ukrainians." 98

Snyder dissects hunger as "a form of aggression" in Stalin's "Ukrainian national struggle," an aggression engineered through distribution: as late as November 1932, Stalin could still have saved "millions of lives without drawing any outside attention," merely by suspending food exports "for a few months," releasing grain reserves, or giving peasants "access to local grain storage areas." Snyder pinpoints "crucial policies" that were "applied only, or mainly, in Soviet Ukraine in late 1932 or early 1933," such as sealing the republic's borders, thus preventing starving peasants from fleeing, and confiscating seed grain, with particularly lethal effect and clear criminal-political intent. The upshot was that "those who wished for some autonomy for the Ukrainian republic" or "for themselves and their families" were defeated. "Though collectivization was a disaster everywhere in the Soviet Union, the evidence of clearly premeditated mass murder on the scale of millions is most evident in Soviet Ukraine." $" 99$

Sovietization, Russification, and genocide thus went hand in hand. "Stalin believed that the national question was in essence a peasant question," Snyder notes, "and as he undid Lenin's compromise with the peasants he also found himself undoing Lenin's compromise with the nations."100 Terry Martin depicts the years from 1933 to 1938 as the period of "great retreat" in the Soviet nationalities policy: the "Piedmont Principle" was abandoned in favor of a "defensive foreign policy stance," eventually leading to "ethnic cleansing and mass arrests and executions among the Soviet Union's diaspora nationalities," now suspected of being "disloyal because of their national identity alone." "Most dramatically, 
the Russian nationality and Russian culture were rehabilitated. The Russians and Russian culture were now made the unifying force in a newly imagined Friendship of the Peoples." 101

One scholar observes that "Nazi policies toward Ukrainians were more severe than Soviet policies." 102 But Nazi Germany was, after all, an invader with an explicitly racist, enslaving and exterminatory geopolitical agenda. By contrast, Soviet policies in Ukraine hit defenseless compatriots; and unlike Russia, Germany never saw, or portrayed itself as a "conational," a relative, or "big brother" of Ukraine.

In the end, both Hitler's and Stalin's "utopias of control overlapped in Ukraine": Ukraine "was the place that would enable them to break the rules of traditional economics, rescue their countries from poverty and isolation, and remake the continent in their own image." 103

\section{RUSSIFICATION}

As a result of "World War II, the Holocaust, and forced population exchanges with Poland," Ukraine (like Poland) "lost much of its rich multiethnic past." Meanwhile, "the influx of ethnic Russians and assimilationist pressures prompting Ukrainians to switch to the Russian language" rendered the republic "more culturally 'Russian." "104 Already before the war, "the demographic balance in Soviet Ukraine shifted in favor of Russians" owing to the Great Famine. ${ }^{105}$ Between 1933 and 1944, Tadeusz Olszanski notes, "old" Ukraine lost "almost one third of its population," down to an estimated 25 million in 1946. But in the 1959 census, Ukraine within its new borders suddenly counted 42 million people. "Such a rapid increase was possible only due to mass immigration." 106 Based on the experiences of Latvia and Estonia, Olszanski assumes that during the postwar period (that is, until 1990) "as much as one third of the population" came to consist of "inter-Soviet migrants" and their descendants, concentrated mainly in the large industrial centers in the east and south, Kyiv, and the Crimea. ${ }^{107}$ "Between 1945 and 1955 alone, about 3.5 million people arrived from all over the Soviet Union in the Donetsk region to work in the mines and factories, many as prisoners," creating a lawless culture from which "the Homo Sovieticus never disappeared." 108

For the Ukrainian language things did not improve after Stalin's death. "The drift toward Russian was accelerated by the language reform of 1958, whose objective was to make Russian the 'second native language' of all non-Russians, though this was done not in order to Russify but in order to Sovietize," Hosking notes. In most republics - though "especially frequently" in Ukraine and Belarus - parents chose the Russian option, "so that their children might have better life chances throughout the USSR." Ukraine's "language and national culture were fading in the face of the Russian linguistic onslaught," Hosking writes. 
In the towns of the east and south, Russian was the most commonly spoken language, though with an admixture of Ukrainian vocabulary, pronunciation, and syntax. In the 1980s three-quarters of the population of Odessa spoke Russian as a native language; less than one-quarter spoke Ukrainian, even then with Russian words mixed in. Most Odessites considered Ukrainian a low-status dialect for country bumpkins. ${ }^{109}$

A literary critic lamented that Ukraine's cities had become "gigantic Russifying mincing-machines." "The greatest threat to a distinct Ukrainian identity," Snyder thinks, "came perhaps from the Brezhnev period. Rather than subordinating Ukraine by hunger or blaming Ukrainians for war, the Brezhnev policy was to absorb the Ukrainian educated classes into the Soviet humanist and technical intelligentsias. As a result, the Ukrainian language was driven from schools, and especially from higher education." 111

Still, union republics with access to nation-building means formed the framework for dissolution once the union became mired in crisis. ${ }^{112}$ Independence altered the playing field for Ukrainian. Throughout 1989 and 1990, inspired by developments in the "satellite states" and the Baltic countries, secessionist sentiment spread "from Galicia to other regions of the republic." The March 1991 miners' strikes in eastern Ukraine and the August 1991 coup "constituted further critical tipping points of opinion in Eastern and Southern Ukraine," resulting in December 1991 in "an overwhelming vote in favor of independence," 90 percent, though in the Crimean peninsula only "a bare majority of 54 percent." 113 Crimea, transferred to Ukraine in 1954, had been thoroughly "cleansed" of Tatars during the war (as well as of Greeks, Bulgarians, and Armenians); its inhabitants consisted largely of postwar "inter-Soviet" immigrants. ${ }^{114}$ The 1991 referendum had been "framed" to benefit Ukrainian independence, excluding union, while "a large part" of the public "remained remarkably apathetic." 115

Enshrined as the state language in a 1989 language law passed by the Soviet Ukrainian parliament and, after independence, in the 1996 constitution, Ukrainian did remain under pressure. "An ambivalent state policy," Volodymyr Kulyk decries, "sought to promote Ukrainian without prohibiting or, in most cases, even inhibiting the use of Russian in the public domain."116 Yet when ethnic Ukrainians had shifted to Russian under Sovietizing pressure, this "did not mean that they more strongly identified with 'Russians' or 'Russian speakers' as a group," which helps to explain the lack of resistance to the promotion of Ukrainian in education after independence. ${ }^{117}$

During protests against a 2012 language law sponsored by President Yanukovych's Party of Regions that lent official status to Russian, Vitali Klitschko wondered, "Why is the main language in Germany German? Why is the main language in France French?" 118 Clearly the imperial legacy in Ukraine, "home to the largest population of Russian speakers outside Russia,"119 complicates 
matters. In the tsarist and Soviet empires, Russian language had been the key that provided access to a broader socioeconomic and cultural context, and to greater opportunities. The collapse of the Soviet Union turned oppressed and disdained languages into vehicles of emancipation and keys to a far larger context, that of Europe and the world, from which the Soviet empire had cut off its subjects. The linguistic nationalism of the Baltic states was aimed not at provincial retrenchment but, on the contrary, at gaining — at last — access to Europe and the world. In Ukraine a similar logic hadn't come to fruition.

Why? As Laitin notes, in their attempt to stem or reverse "a Soviet-inspired identity project that emphasized the merging of nations," a key challenge for nationalists "is to induce their followers to abjure the central language. An important element for success is to get people from the regional culture to believe that all their fellow regionals are already beginning to switch to a regional-dominant language repertoire." Here the contrast between Ukraine and the Baltic states could not be greater: "With virtually all Balts fluent in the titular language, and with Russian thoroughly discredited as an alternative, the cascade to 100 percent compliance with the titular regime (for the titular population) was instantaneous." The collapse of the USSR meant the restoration of the interwar Baltic republics, "rather than the independence of Soviet-created Union republics." This way, "Russian-speakers who immigrated in the Soviet period could be denied the right to vote, on the grounds that they were illegal immigrants who had never been naturalized under republican law." Hence nationalist candidates in post-Soviet elections did not have to worry about "a Russian vote that would undermine the culturalist program," and the "titulars" were "determiners of their own fate." In addition, Russia exerted little attraction in the Baltic states:

\footnotetext{
Because the political and economic systems in the Baltics were far more stable than in Russia or Ukraine, most Russian-speakers had no interest in leaving. Furthermore, their respect for the Balts as Europeans, as having a window on Europe and the Western world, gave Russian-speakers a strong disincentive to pack their suitcases.
}

In 1998 Laitin predicted that, "given the status gains that can be achieved intergenerationally in the Baltics, the trend will be for sustained assimilation into the Latvian and Estonian cultures." In Ukraine, by contrast, "if the cascade of ukrainization does not spread east, and the country's language issue remains unresolved, Russian-speakers (made up of all nationality groups) will continue to exert pressure on the government as a major political force." 120

More than ten years after Laitin's prediction, Kulyk confirmed that, "notwithstanding changes in the language regime of education" in independent Ukraine, the "Russification of rural migrants to cities" was continuing. ${ }^{121}$ Ukrainian still faced huge odds in the media and in publishing, where the predominance of 
Russian remained overwhelming. ${ }^{122}$ Overall, Kulyk observes, "younger generations speak Russian not less, but more than their parents or grandparents." This was true even for "rural youth," presumably due to their "more intense contacts with the cities," or to Russian's "image of being more modern and suitable" for domains that youngsters are "particularly interested in (e.g., technology, business, or popular music)." ${ }^{123}$ Thus, Russian continued to be the language of modernity, innovation, and the wider world, a role that for the past several decades had been assumed by English in the EU.

Better-educated Ukrainians under the age of forty-five showed "stronger support for the use of Ukrainian in society." Yet in both Russian and Ukrainian language groups "the strongest supporters of the spread and promotion of Ukrainian" were the better off; they also were "more supportive of Ukrainian becoming the main language of all social domains in the future." 124 In Olszanski's opinion, Ukrainian still needs "some kind of affirmative action." 125 With the 2012 language law, however, exactly the opposite began to happen; speaking of Kharkiv, the Russian-language novelist Andrey Kurkov noted with bewilderment that, after twenty years of attempts to bring Ukrainian back into the city, the Yanukovych government "strangely enough has actively started to defend the Russian language." 126

The sensitivity of the issue was highlighted when parliament, "a mere 24 hours after the collapse of the Yanukovych regime" on 22 February 2014, in one of its first acts, rescinded the 2012 language law. The decision was "rushed" and "unwise"; 127 and although subsequently vetoed by the interim president, the damage had been done, as it proved an effective Russian propaganda tool, helping to fuel uncertainty and unrest in the southeast. Formally, the 2012 language law aimed at protecting a host of minority languages that, when spoken by 10 percent or more of the population within an administrative region, could be used officially alongside Ukrainian. Critics feared that the optically liberal law in fact "wanted to pave the way for actual unilingualism in the east and south and the predominance of Russian nationwide," 128 undermining "the hard-won status of Ukrainian as the unifying state language." 129 The OSCE High Commissioner on National Minorities denounced the "disproportionate favoring of the Russian language" and the removal of "most incentives for learning or using Ukrainian in large parts of the country." "130 By the time Yanukovych was toppled Russian had acquired official status in half of Ukraine's regions (thirteen out of twentyseven) ${ }_{131}$ while "Hungarian, Moldovan and Rumanian were declared official languages in several towns in Western Ukraine." 132

European bilingualism, critics of the 2012 language law stated, is not viable "in a lawless post-Soviet country," as "any bilingualism here would be Soviet, rather than European"; 133 "no one" believed local bureaucrats would accommodate Ukrainian-speakers where they formed a minority. ${ }^{134}$ Yet bilingualism can be a tall order even in societies more familiar with the rule of law, as experience in 
Brussels attests. ${ }^{135}$ The problem, then, is not just "Soviet bureaucracy" and a deficient rule of law, but also a deeply ingrained imperial reflex. Referring to a Russian-Estonian activist defending the cause of ethnic Russians, Laitin nicely depicts this reflex:

\begin{abstract}
Pavel's monolingualism was as natural to him as it is to nearly all thirdgeneration Americans. He had travelled as far east as Samarkand, as far south as Sukumi, as far north as Murmansk, and could communicate with anyone in Russian. For Pavel it was as if the whole world spoke Russian; what need did he have for a second language?...Seven time zones, he was fond of pointing out, all you need is Russian....Still, he is making sure his children are equipped... for the new reality. ${ }^{136}$
\end{abstract}

In Estonia this new reality meant learning Estonian, a Finno-Ugric language, in order to be able to acquire full citizenship rights. Laitin notes that "Russians' assimilation is more problematic in culturally proximate Ukraine than in the culturally distant Baltic states." 137

Language, one scholar remarked, is a "symbol," but not the real issue, of Ukrainian nationalism: Ukrainian identity does not stand or fall with the Ukrainian language, "just as the Irish nation has persisted after the virtual disappearance of Gaelic." 138 To some scholars, Ukraine constitutes a prime example of a multinational "state-nation," 139 in contrast with a nation-state or "nationalizing state"140 that pursues cultural homogeneity. Others, however, see language as an indispensable "marker" without which "the Ukrainian state would be hard pressed to define itself as different from Russia." 141 After annexing Crimea, Moscow insisted that Russian become the second state language in Ukraine. Some analysts concurred. ${ }^{142}$ Yet promoting Russification and thwarting Ukrainization is part of a geopolitical project. ${ }^{143}$ Putin stated unambiguously: "We must promote Russian culture there instead of removing it." 144 In Ukraine, according to a 2014 survey, "support for a Ukrainian-only policy is widespread in the far west (79\%), but a majority (56\%) in the center west also agrees. In the east, opinion is the reverse- $25 \%$ say just Ukrainian should be legally recognized, while 73\% say both." 145 The challenge remains to accommodate Russian speakers in a way that does not perpetuate the logic of Russification. ${ }^{146}$ "The experience of Belarus amply demonstrates what two state languages actually mean in practice in the post-Soviet world-only Russian will be used."147

Kulyk emphasizes language identity: he distinguishes between, on the one hand, "communicative practices" and, on the other, the "identification with a particular language or languages" - often reported in censuses as "native language" or mother tongue, whose relevance, he thinks, is underestimated by many a social scientist. In Ukraine, Kulyk posits, language identity is a "powerful predictor of people's attitudes and policy preferences" with regard to not only language 
use but also "other socially divisive issues, such as foreign policy and historical memory." 148 A 2014 survey did suggest that "Russian-only speakers" (43 percent of people in eastern Ukraine) tend to go against the national grain and hold strong pro-Russian views, not only on recognizing Russian as an official languagerather logical from their perspective (86 percent in favor, vs. 54 percent in Ukraine as a whole), but also on Kyiv recognizing the results of the March 2014 Crimean referendum organized under Russian control (61 percent in favor, vs. 30 percent in Ukraine as a whole). Despite Crimea's annexation, the massing of Russian troops on Ukraine's border, and the eruption of armed pro-Russian rebellion in the east, a strikingly high proportion of Russian-only speakers continued to express confidence in Putin's handling of international affairs ( 43 percent) and to assess Russia's influence on developments in Ukraine as "positive" (41 percent), whereas "most Ukrainians" had very much "soured on Russia"- 87 percent in the west described Russia's influence on Ukraine as "bad," and even in the east 58 percent shared that negative view. ${ }^{149}$ This, of course, is not meant to suggest that Russian speakers would somehow be predestined to reproduce neo-Soviet values and reflexes, only that, beyond its sheer cultural merits, nurturing Ukrainian can have political implications in helping the battered nation consolidate its identity and emancipate itself from its former imperial overlord. Moscow certainly has a clear understanding of the implications.

\section{COLLeCtive Memory}

In an attempt to roll back Russia's appropriation of East Slavic history, Ukrainian nation builders claimed Kyivan Rus' for their own historical narrative and national symbols:

\footnotetext{
The view that the Ukrainians were the true heirs of the Rus' legacy, which was confined to Ukrainian émigré publications before 1991, has gained a new lease on life in independent Ukraine on both the academic and popular levels. In Ukrainian public discourse, Kyivan Rus' emerged as the first Ukrainian state, the images of Rus' princes appeared on Ukrainian bank notes, and the symbol of the Kyivan princes, the trident, was adopted as the coat of arms of an independent Ukraine. Cathedrals and monasteries dating back to Kyivan Rus' and destroyed by the Bolshevik regime were restored by the Kyiv city authorities, as was the monument to the first Christian princess, Olha (Olga), in downtown Kyiv. ${ }^{150}$
}

Particularly after the Orange Revolution of 2004, Ukrainian nation builders rekindled the memory of the Great Famine or Holodomor, inserting it into an explicitly national narrative, though this was "often resisted by regional politi- 
cal elites in Southern and Eastern Ukraine." ${ }^{151}$ Hardcore resistance persisted against one of the least contested facts in the scholarly literature, namely that the famine was brought about "by design," 152 hence not by accident — " "the result of difficult circumstances." 153 The perception of the Great Famine is influenced by regional differences; ${ }^{154}$ areas worst hit by the famine appear least inclined to see criminal intent behind it. ${ }^{155}$ After all, the famine was a highly effective Sovietization method.

Differing perceptions of the past go hand in hand with "differing visions of the nation's future." 156 While overall levels of Soviet nostalgia were comparable to other post-Soviet states (except, of course, in the Baltic states), ${ }^{157}$ a survey question (asked before the Russian invasions) whether Stalin was "a great leader" revealed substantial regional differences: west, 52 percent "no" vs. 28 percent "yes"; center, 30 percent vs. 33 percent; south, 27 percent vs. 41 percent; east, 29 percent vs. 43 percent. Overall, pensioners and people with a low educational level appeared more appreciative of Stalin's leadership. ${ }^{158}$ Strong ties with the EU_-increasingly contentious in late 2013 and early 2014 - were most supported in the west ( 68 percent), least in the east ( 21 percent, 12 percent among Russianonly speakers). Overall, younger Ukrainians (ages eighteen to twenty-nine) were more supportive of strong ties with the EU (53 percent) than those fifty or older (36 percent). ${ }^{159}$

Support for pro-Russian separatism or secession appeared low, even in Ukraine's southeast. ${ }^{160}$ In the run-up to Ukraine's successful presidential election on 25 May 2014, in which "voters expressed a clear choice for Europe, for reforms, and for a united country,"161 the Kremlin toned down its language and some of its claims - notably the "Novorossiya" scenario, but retained "plenty of scope" for "mischief making and meddling." 162 During the second half of August 2014, Moscow intervened in an increasingly brazen manner in order to reverse the declining fortunes of pro-Russian rebels in eastern Ukraine- - an intervention it "blithely" denied "despite incontrovertible evidence."163 Thus Putin laid the groundwork for yet another Russian-supported frozen conflict. The motives appeared strategic, not irredentist, namely gaining extra leverage over Ukraine. Straightforward occupation would have defeated the purpose: "eastern Ukraine is one of the few places beyond Russia's borders in which Moscow can deliver the assets to sustain an insurgency."164

At the time of the Yanukovych presidency, a Russian observer noted that Moscow was quietly "waiting for the general situation in Ukraine to deteriorate to the point where Kiev won't have any choice but to consider Russia's integration proposals, primarily membership in the Customs Union," 165 now commonly called "Eurasian Union"-Putin's pet project. That union, it was candidly admitted, "is in fact not focused on Eurasia as a whole but on one particular country that is actually located in Europe-Ukraine." "166 The Eurasian Union was conceived as "a grand imperial vision" designed "to rival the EU." And it had to include 
Ukraine, or else Putin himself would have seen it as "a failure." Hence Moscow needed "a pliable authoritarian Ukrainian neighbor." 167

When the Eurasian scheme suffered a severe setback, owing to Ukrainians' resistance and extraordinary endurance, Moscow invaded, grabbed territory, massed troops, launched an all-out media war questioning the legitimacy of the interim ("fascist") government installed after Yanukovych fled to Russia ("the coup"), fomented fear, rebellion, and instability, and dictated sweeping demands. "Long-term stabilization of the Ukrainian state," Russia's foreign ministry threatened, could "hardly be expected" without far-reaching "constitutional reform" designed to ensure Ukraine's "neutral status," "strengthen the special status of the Russian language," and introduce "federalization."168 The federalization prescribed for Ukraine would be totally inconceivable inside Putin's Russia. ${ }^{169}$ It entails giving Ukraine's regions "wide powers" to establish "economic and cultural ties with neighboring countries," 170 enabling them, for instance, "to join a trading bloc led by Russia."171 A Russian academic defending the Kremlin's revisionism praised "the Dayton model":

By giving a special status to Donbas and legalizing its pro-Russian positioning (this may apply to other regions in the south-east of Ukraine as well), it will dramatically limit a 'Bosnianized' Ukraine's legal capacity as an international actor. ${ }^{172}$

A supposedly milder, "fairly cumbersome" Russian recipe would slice the country into "autonomous entities" that "could be linked with the center by a system of intra-state treaties and form parts of the Ukrainian state." 173 Yet whatever the recipe and its details, the aim clearly was to cripple the country's central government. ${ }^{174}$

Liberal Russian analysts worry about the Kremlin's conservative, anti-Western turn in its attempt to preserve "the state system...established in Russia over the last twenty years":

In 2012-2013, the new ruling class in Russia regarded mass protests in the country as a Western-inspired attempt to organize a color revolution. Apparently, the Kremlin came to the conclusion that further rapprochement with the U.S. and the EU was dangerous. It therefore abandoned the policy of 'European choice for Russia,' which was officially proclaimed in the 1990s and during the first period of Putin's rule... and replaced it with the doctrine of 'Eurasianism.' 175

As a result, the "Partnership for Modernization" with the West was replaced by a policy of reindustrializing the economy with heavy emphasis on the defense industry. "This U-turn has been accompanied by a propaganda campaign, unprecedented since the Cold War times, about a military threat from the West." Ukraine 
being central to the Kremlin's "Eurasian" scheme, that country's turn to Europe was depicted as an existential threat. ${ }^{176}$

Russia's actions in Ukraine may not be as self-evident and as reactive to Western initiatives as some like to suggest, reasoning in a rather schematic "realist" mode that ignores both autocratic regression and democratic aspirations. ${ }^{177}$ Liberals inveigh against the "pernicious rehabilitation of Stalinism in Russia," and the "heroic resonance" that is "increasingly often" given to the term imperialism. ${ }^{178}$

Clearly, imperial narratives and attitudes remain a heavy burden on Ukraine. They must be subjected to effective criticism (not countered with a primordialist Ukrainian narrative). ${ }^{179}$ Ukraine's travails are part and parcel of a protracted decolonization drama compounded by a harrowing history. "The tradition of

all the dead generations weighs like a nightmare on the brain of the living," 180 a renowned thinker once wrote. Transcending the imperial legacies remains crucial for Ukraine in order to develop its identity and autonomy.

\section{NOTES}

1. "Address of the President of the Russian Federation," Website of the President of Russia, 18 March 2014, http://eng.kremlin.ru/news/6889.

2. Andrew Wilson, The Ukrainians: Unexpected Nation (New Haven: Yale University Press, 2002), 20.

3. Sergei Lavrov, “Ukraine Not Russia's Backyard, Ria Novosti, 14 May 2014, in Johnson's Russia List, 2014, no. 107, http://russialist.org/ria-novosti-ukraine-notrussias-backyard-lavrov.

4. Jeffrey Tayler, "The Next Flashpoint: Ukraine," The Atlantic online, 8 September 2008, http://www.theatlantic.com/magazine/archive/2008/09/the-next-flashpointukraine/307013.

5. Steven Lee Myers, "Putin Engages in Test of Will over Ukraine," New York Times, 3 March 2014, A1.

6. Kevin M. F. Platt, "Russia's Powerful Media Bubble," Huffington Post, 19 March 2014, http://www.huffingtonpost.com/kevin-m-f-platt/russias-powerful-mediabubble_b_4995783.html.

7. "Direct Line with Vladimir Putin" [transcript], 17 April 2014, Website of the President of Russia, http://eng.kremlin.ru/transcripts/7034.

8. Jeffrey Mankoff, "Russia's Latest Land Grab: How Putin Won Crimea and Lost Ukraine,” Foreign Affairs 93, no. 3 (May-June 2014), http://www.foreignaffairs. com/articles/141210/jeffrey-mankoff/russias-latest-land-grab.

9. Timothy Snyder, "The Battle in Ukraine Means Everything," New Republic, 11 May 2014, http://www.newrepublic.com/article/117692/fascism-returns-ukraine.

10. See William W. Burke-White, "Crimea and the International Legal Order," Survival: Global Politics and Strategy 56, no. 4 (August-September 2014): 68.

11. Sergei Lavrov, cited in "John Kerry in Paris for Talks with Sergei Lavrov," FT.com, 
30 March 2014, http://www.ft.com/cms/s/0/695c34f8-b801-11e3-92f9-00144feabdc0. html\#ixzz2xU4a3fHI.

12. "Direct Line with Vladimir Putin."

13. The remarks were made to U.S. President George W. Bush at the April 2008 NATO summit in Bucharest. Tayler, "The Next Flashpoint: Ukraine." See also the 14 August 2008 cable by the then U.S. Permanent Representative to NATO Kurt Volker, https:// wikileaks.org/plusd/cables/08USNATO290_a.html, no. 3.

14. "Direct Line with Vladimir Putin."

15. Tarik Cyril Amar, "This Is No Second Cold War: Ukraine's Territorial Integrity Must Remain Intact,” Guardian, 28 February 2014, http://www.theguardian.com/ commentisfree/2014/feb/28/ukraine-this-is-no-second-cold-war.

16. Serhii Plokhy, The Origins of the Slavic Nations: Premodern Identities in Russia, Ukraine, and Belarus (Cambridge: Cambridge University Press, 2006), 12, also 138-40, 151-56.

17. Ibid., 17.

18. Ibid., 85 .

19. Ibid., 140 .

20. Norman Davies, Vanished Kingdoms: The History of Half-Forgotten Europe (London: Allen Lane, 2011), 244, 252-53.

21. Timothy Snyder, "Putin's Project," FAZ.NET, 16 April 2014, http:/www.faz.net/ aktuell/politik/ausland/timothy-snyder-about-europe-and-ukraine-putin-s-project-12898389.html.

22. Plokhy, Origins of the Slavic Nations, 158.

23. Ibid., 46-47, 83.

24. E.g., Heinz Theisen, Die Grenzen Europas: Die Europäische Union zwischen Erweiterung und Überdehnung (Opladen: Budrich, 2006), 196; also Richard Wagner, "Why Ukraine has no place in the EU," signandsight.com, 11 June 2008, http://www.sign andsight.com/features/1708.html.

25. Timothy Snyder, The Reconstruction of Nations: Poland, Ukraine, Lithuania, Belarus, 1569-1999 (New Haven: Yale University Press, 2003), chap. 6.

26. Roman Szporluk, "Ukraine: From an Imperial Periphery to a Sovereign State," Daedalus 126, no. 3 (Summer 1997): 85-87.

27. Hosking, Rulers and Victims, 14-15.

28. Timothy Snyder, Bloodlands: Europe between Hitler and Stalin (London: Vintage, 2011), 6 .

29. Hosking, Rulers and Victims, 82.

30. Terry Martin, The Affirmative Action Empire: Nations and Nationalism in the Soviet Union, 1923-1939 (Ithaca, N.Y.: Cornell University Press, 2001), 206.

31. Norman M. Naimark, Stalin's Genocides (Princeton: Princeton University Press, 2010), 84 .

32. Snyder, Bloodlands, 96; see also Naimark, Stalin's Genocides, 85 (in a slightly different translation). 
33. Snyder, Bloodlands, 102-4.

34. Naimark, Stalin's Genocides, 90-92; Molotov quote p. 92.

35. Szporluk, "Ukraine," 87, see also 110.

36. Wilson, The Ukrainians, 149.

37. Vera Tolz, "Rethinking Russian-Ukrainian Relations: A New Trend in Nation-Building in Post-Communist Russia?" Nations and Nationalism 8, no. 2 (2002): 236.

38. Richard Pipes, Russia under the Old Regime (London: Penguin, 1995), 118 and passim; Pipes, Russian Conservatism and Its Critics: A Study in Political Culture (New Haven: Yale University Press, 2005).

39. Simon Dixon, The Modernisation of Russia, 1676-1825 (Cambridge: Cambridge University Press, 1999), 23-24.

40. Geoffrey Hosking, Russia: People and Empire, 1552-1917 (London: Fontana, 1998), xxiv, xxvii.

41. Plokhy, Origins of the Slavic Nations, 133-34; cf. Pipes, Russia under the Old Regime.

42. Stéphane Courtois, "Pourquoi?" in Le livre noir du communisme: Crimes, terreur, répression, by Stéphane Courtois et al. (Paris: Laffont, 1998), 858. Here and elsewhere, all translations are my own.

43. Szporluk, "Ukraine," 111. On the role of elite conceptualization of the nation, see Benedict Anderson, Imagined Communities: Reflections on the Origin and Spread of Nationalism (London: Verso, 2006).

44. Andreas Kappeler, Der schwierige Weg zur Nation: Beiträge zur Geschichte der Ukraine (Vienna: Böhlau Verlag, 2003), 117. The involvement of intellectuals from other backgrounds is far from atypical for fledgling national movements; see Miroslav Hroch, Social Preconditions of National Revival in Europe: A Comparative Analysis of the Social Composition of Patriotic Groups among the Smaller European Nations, trans. Ben Fowkes (Cambridge: Cambridge University Press, 1985).

45. Serhii Plokhy, The Cossack Myth: History and Nationhood in the Age of Empires (Cambridge: Cambridge University Press, 2012), 5.

46. Roman Szporluk, "Reflections on Ukraine after 1994: The Dilemmas of Nationhood," in Russia, Ukraine, and the Breakup of the Soviet Union (Stanford: Hoover Institution Press, 2000), 337.

47. David R. Marples, "Ethnic Issues in the Famine of 1932-1933 in Ukraine," EuropeAsia Studies 61, no. 3 (May 2009): 510. See also Kappeler, Der schwierige Weg zur Nation, 61-63, aiming particularly at German scholarship.

48. Zenon E. Kohut, "History as a Battleground: Russian-Ukrainian Relations and Historical Consciousness in Contemporary Ukraine," in The Legacy of History in Russia and the New States of Eurasia, ed. S. Frederick Starr (Armonk, N.Y.: Sharpe, 1994), 123.

49. Tolz, "Rethinking Russian-Ukrainian Relations," 237, 241-42, 250. See also Andreas Kappeler, "Ukraine and Russia: Legacies of the Imperial Past and Competing Memories," Journal of Eurasian Studies 5, no. 2 (July 2014): 107-15, http://dx.doi. org/10.1016/j.euras.2014.05.005. 
50. Wolfgang Templin, Farbenspiele — die Ukraine nach der Revolution im Orange (Bonn: Bundeszentrale für politische Bildung, 2008), 84.

51. Andreas Umland, "Courting Little Russia: Europe's Path to Moscow Leads through Kiev,” IP Journal, 1 May 2011, https://ip-journal.dgap.org/en/ip-journal/regions/ courting-little-russia.

52. Fyodor Lukyanov, "Kiev Plays without Rules and Risks It All," Russia in Global Affairs, 14 October 2011, http://eng.globalaffairs.ru/redcol/Kiev-plays-without-rulesand-risks-it-all-15348.

53. Szporluk, "Reflections on Ukraine after 1994," 335.

54. Dominique Arel, "Ukraine since the War with Georgia," Survival: Global Politics and Strategy 50, no. 6 (December 2008-January 2009): 21.

55. Tony Barber, "Putin Bites at the West Where His Predecessors Growled," FT.com, 21 March 2014, http://www.ft.com/cms/s/0/aa6f7bee-b112-11e3-bbd4-00144feab7de. html\#ixzz2whfBHS1X.

56. Mark Kramer, "It's Happened Before: MH17 Tragedy was Part of a Bigger Air War," CNN.com (Opinion), 24 July 2014, http://us.cnn.com/2014/07/23/opinion/kramerrussia-ukraine-shoot-down/index.html?hpt=op_t1.

57. Serhii Plokhy, interview in Vostok Cable, 26 June 2014, http://vostokcable.wordpress. com/2014/06/26/a-turbulent-time/.

58. Wilson, The Ukrainians, 298.

59. Szporluk, "Reflections on Ukraine after 1994," 335.

60. Serhy Yekelchyk, Ukraine: Birth of a Modern Nation (Oxford: Oxford University Press, 2007), 38.

61. Tolz, "Rethinking Russian-Ukrainian relations," 239.

62. Serhy Yekelchyk, Stalin's Empire of Memory: Russian-Ukrainian Relations in the Soviet Historical Imagination (Toronto: University of Toronto Press, 2004): 4-5.

63. Kappeler, Der schwierige Weg zur Nation, 50.

64. Wilson, The Ukrainians, 214.

65. David Laitin, Identity in Formation: The Russian-Speaking Populations in the Near Abroad (Ithaca, N.Y.: Cornell University Press, 1998), 33, 59-67.

66. Ibid., 64, referring to Robert J. Kaiser, The Geography of Nationalism in Russia and the USSR (Princeton: Princeton University Press, 1994).

67. E.g., Taras Kuzio, "History, Memory and Nation Building in the Post-Soviet Colonial Space," Nationalities Papers 30, no. 2 (2002): 241-64; Mykola Riabchuk, "Culture and Cultural Politics in Ukraine: A Postcolonial Perspective," in Dilemmas of State-Led Nation Building in Ukraine, ed. Taras Kuzio and Paul D'Anieri (Westport: Praeger, 2002), 47-69.

68. In his study of rural France's modernization and its conquest by French culture, Eugen Weber notes, "What happened was akin to colonization, and may be easier to understand if one bears that in mind." See his Peasants into Frenchmen: The Modernization of Rural France, 1870-1914 (Stanford: Stanford University Press, 1976), 486. Needless to say, in Ukraine such processes took on a sharper edge. 
69. Plokhy, interview in Vostok Cable; see also Plokhy, The Last Empire: The Final Days of the Soviet Union (New York: Basic Books, 2014).

70. Yekelchyk, Ukraine, 57; see also Wilson, The Ukrainians, 79.

71. Hosking, Rulers and Victims, 15.

72. Wilson, The Ukrainians, 78.

73. Hosking, Russia: People and Empire, 379.

74. Ivan L. Rudnytsky, "The Ukrainians in Galicia under Austrian Rule," in Nationbuilding and the Politics of Nationalism: Essays on Austrian Galicia, ed. Andrei S. Markovits and Frank E. Sysyn (Cambridge, Mass.: Harvard Ukrainian Research Institute, 1982), 23-67 (Ievhen Chykalenko cited p. 51); Andrei S. Markovits, "Introduction: Empire and Province," in Markovits and Sysyn, Nationbuilding and the Politics of Nationalism, 1-22; Paul Robert Magocsi, The Roots of Ukrainian Nationalism: Galicia as Ukraine's Piedmont (Toronto: University of Toronto Press, 2002).

75. Keith Darden, "How to Save Ukraine," foreignaffairs.com (Postscript), 14 April 2014, http://www.foreignaffairs.com/articles/141182/keith-darden/how-to-save-ukraine.

76. Martin, Affirmative Action Empire, 78.

77. Ibid., 9, 78, 274.

78. Hosking, Rulers and Victims, 144.

79. Martin, Affirmative Action Empire, 77

80. Ibid., 77, 122-23.

81. Ibid., 274, 282, 288-89.

82. Andrea Graziosi, "The Soviet 1931-1933 Famines and the Ukrainian Holodomor," in Hunger by Design: The Great Ukrainian Famine and Its Soviet Context, ed. Halyna Hryn (Cambridge, Mass.: Harvard Ukrainian Research Institute, 2008), 9; see also Martin, Affirmative Action Empire, 305.

83. Martin, Affirmative Action Empire, 133.

84. Ibid., 34.

85. Hosking, Rulers and Victims, 102, 104.

86. Marples, "Ethnic Issues in the Famine of 1932-1933," 511-16.

87. Widely quoted, notably in Hosking, Rulers and Victims, 103; Graziosi, "Soviet 1931-1933 Famines," 7; in a slightly different translation, Martin, Affirmative Action Empire, 297-98.

88. Graziosi, "Soviet 1931-1933 Famines," 8.

89. Martin, Affirmative Action Empire, 298.

90. Snyder, Bloodlands, 38.

91. Martin, Affirmative Action Empire, 302, 305.

92. Nicholas Werth, "Un état contre son peuple: violences, répressions, terreurs en Union Soviétique," in Courtois et al., Le livre noir du communisme, 196-97.

93. Wilson, The Ukrainians, 145-46.

94. Nicholas Werth, "Keynote Address to the Holodomor Conference, Harvard Ukrainian Research Institute, 17-18 November 2008," Harvard Ukrainian Studies 30, no. 1-4 (2008): xxxv-xxxvi. 
95. Graziosi, "Soviet 1931-1933 Famines," 3, 8, 11. For similar assessments, see Naimark, Stalin's Genocides, 78-79, 81; James Mace, "Famine and Nationalism in Soviet Ukraine," Problems of Communism 33, no. 3 (May-June 1984): 37-50; and Norman Davies, Europe: A History (London: Pimlico, 1997), 965.

96. Naimark, Stalin's Genocides, 93.

97. George G. Grabowicz, "The Holodomor and Memory," in Hryn, ed., Hunger by Design, 132. Naimark speaks of "six to eight million" victims for the Soviet Union as a whole, and "three to five million" for Ukraine and "the heavily Ukrainian-populated Northern Kuban" (Stalin's Genocides, 70).

98. Snyder, Bloodlands, 53-54.

99. Ibid., 41-46, 54.

100. Ibid., 44.

101. Martin, Affirmative Action Empire, 26-27.

102. Ivan Katchanovski, "The Politics of Soviet and Nazi Genocides in Orange Ukraine," Europe-Asia Studies 62, no. 6 (August 2010): 995.

103. Snyder, Bloodlands, 19.

104. Yekelchyk, Ukraine, 153.

105. Snyder, Bloodlands, 52.

106. Tadeusz A. Olszanski, "The Language Issue in Ukraine: An Attempt at a New Perspective," OSW Studies (Warsaw), no. 40 (May 2012), 10, http://www.osw.waw. pl/en/publikacje/osw-studies/2012-05-16/language-issue-ukraine-attempt-a-newperspective.

107. Ibid., 11-12.

108. Piotr H. Kosicki and Oksana Nesterenko, "Eastern Ukraine Has Been a Mafia State for Years: Can Kiev Break the Cycle of Violence?” New Republic, 5 June 2014, http:// www.newrepublic.com/article/118010/eastern-ukraine-mafia-state-can-kiev-imposerule-law.

109. Hosking, Rulers and Victims, 322-24.

110. Ibid., 324, citing Ivan Dziuba.

111. Snyder, "The Battle in Ukraine Means Everything."

112. See Philip G. Roeder, Where Nation-States Come From: Institutional Change in the Age of Nationalism (Princeton: Princeton University Press, 2007).

113. Mark R. Beissinger, Nationalist Mobilization and the Collapse of the Soviet State (Cambridge: Cambridge University Press, 2002), 191, 193, 197-198.

114. Olszanski, Language Issue in Ukraine, $10 \mathrm{n} 6$.

115. Henry E. Hale, The Foundations of Ethnic Politics: Separatism of States and Nations in Eurasia and the World (Cambridge: Cambridge University Press, 2008), esp. chap. 7 , quote on 153 . Twenty years later, polls suggested support for independence ranging from 64.4 to 82.6 percent (see Razumkov Centre, August 2012 poll, http://www. razumkov.org.ua/eng/poll.php?poll_id=320; Kiev International Institute of Sociology [KIIS], “Citizens' Attitudes towards Ukraine's Independence,” November 2011 survey, http://kiis.com.ua/img/pr_img/20111201_indep/indepENG.pdf). 
116. Volodymyr Kulyk, "Language Identity, Linguistic Diversity and Political Cleavages: Evidence from Ukraine," Nations and Nationalism 17, no. 3 (2011): 633.

117. Alexandra Hrycak, "Institutional Legacies and Language Revival in Ukraine," in Rebounding Identities: The Politics of Identity in Russia and Ukraine, ed. Dominique Arel and Blair A. Ruble (Baltimore: Johns Hopkins University Press, 2006), 65.

118. Cited in "In Ukraine, Official Quits to Protest Bill on Russian," New York Times, 5 July 2012, A4.

119. Hrycak, "Institutional Legacies and Language Revival," 63.

120. Laitin, Identity in Formation, 25, 353-54, 363.

121. Volodymyr Kulyk, "The Demography of Language Practices and Attitudes in Ukraine," Harvard Ukrainian Studies 29, no. 1-4 (2007): 298.

122. Olszanski, Language Issue in Ukraine, 24-35.

123. Kulyk, "Demography of Language Practices," 303-4.

124. Ibid., 304, 316, 321-22, 324.

125. Olszanski, Language Issue in Ukraine, 50.

126. Andrej Kurkow [Andrey Kurkov], "Polit-Touristen, kommt nach Charkiw!” Die Zeit, 26 June 2012, http://www.zeit.de/reisen/2012-06/ukraine-charkiv.

127. Dominique Arel, "Double-Talk: Why Ukrainians Fight over Language," 18 March 2014, foreignaffairs.com (Snapshot), http:/www.foreignaffairs.com/articles/141042/ dominique-arel/double-talk.

128. Volodymyr Kulyk, "Language Policy in Ukraine: What People Want the State to Do," East European Politics and Societies 27, no. 2 (May 2013): 303; (OnlineFirst), 26 February 2013, 24, DOI 10.1177/0888325412474684.

129. Steven Pifer and Hannah Thoburn, "What Ukraine's New Language Law Means for National Unity,” Brookings Up Front blog, August 21, 2012, http://www.brookings. edu/blogs/up-front/posts/2012/08/21-ukraine-language-pifer-thoburn.

130. "OSCE High Commissioner on National Minorities Urges Dialogue and Compromise on 'Divisive' Language Law in Ukraine," Organization for Security and Cooperation in Europe (Newsroom), 26 July 2012, http://www.osce.org/hcnm/92418.

131. "Radicals May Push aside Ukrainian Moderate Opposition-Margelov," Interfax, 24 February 2014, http://www.interfax.com/newsinf.asp?id=483197.

132. "Ukraine Abolishes Law on Languages of Minorities, Including Russian," Russia Beyond the Headlines, 23 February 2014, http://rbth.co.uk/news/2014/02/23/ ukraine_abolishes_law_on_languages_of_minorities_including_russian_34486.html.

133. Mykola Riabchuk, "Playing with Ambiguities: Ukraine's Language Law," Open Democracy (oDR), 28 June 2012, http://www.opendemocracy.net/od-russia/mykolariabchuk/playing-with-ambiguities-ukraine $\%$ E2\%80\%99s-language-law.

134. Kostyantyn Dykan, "The Law on Languages Will Make No Difference But Disregard of the Ukrainian-Speakers' Rights," Razumkov Centre (Experts' comments), 6 July 2012, http://www.razumkov.org.ua/eng/expert.php?news_id=3564.

135. One problem, francophone notables complain, is the "dramatically" poor quality of language teaching in Belgium's francophone schools. In Belgium's Dutch-speaking 
north, 66 percent of people aged fifteen to twenty-four are able to have a conversation in French, 81 percent in English; but in the French-speaking south, the figures are 7 percent for Dutch, 30 percent for English. See Grégor Chapelle et al., "Arrêtons le gâchis linguistique dans la capitale de l'Europe!” Le Soir, 13 February 2013, 13, http:// www.uclouvain.be/cps/ucl/doc/etes/documents/2013.02.13.LS.Gachis_Linguistique. pdf.

136. Laitin, Identity in Formation, 8-9.

137. Ibid., 33.

138. Walker Connor, quoted in Szporluk, "Reflections on Ukraine after 1994," 340-41.

139. Alfred Stepan, Juan J. Linz, and Yogenda Yadav, Crafting State-Nations: India and Other Multi-National Democracies (Baltimore: Johns Hopkins University Press, 2011), chap. 6.

140. See Rogers Brubaker, Nationalism Reframed: Nationhood and the National Question in the New Europe (Cambridge: Cambridge University Press, 1996), chap. 4.

141. Taras Kuzio, "The Nation-Building Project in Ukraine and Identity: Toward a Consensus," in Dilemmas of State-Led Nation Building in Ukraine, ed. Taras Kuzio and Paul D'Anieri (Westport: Praeger, 2002), 18.

142. E.g., Tarik Cyril Amar, "Consequences and False Dominoes: The Crisis in and over Ukraine," ukraineanalysis, 20 April 2014, http://ukraineanalysis.wordpress. com/2014/04/20/consequences-and-false-dominoes-the-crisis-in-and-over-ukraine/.

143. Moscow has often raised "the rights of the Russian-speaking community" and the teaching of Russian language and literature in independent Ukraine. While making life extremely difficult for NGOs on its own turf, the Kremlin actively promoted NGOs with "a civilizational pro-Russian orientation," such as the state-funded Russkiy Mir Foundation which, according to Olszanski, sees "hampering the Ukrainization of Ukraine's language sphere" as "one of its crucial goals." Olszanski, Language Issue in Ukraine, 41-42.

144. "Direct Line with Vladimir Putin."

145. Pew Research Center, Despite Concerns about Governance, Ukrainians Want to Remain One Country, 8 May 2014, 10-11, http://www.pewglobal.org/files/2014/05/ Pew-Global-Attitudes-Ukraine-Russia-Report-FINAL-May-8-2014.pdf.

146. One suggestion is to give Russian the status of regional language where the majority of the population wants it, an option that appeared to be preferred by most Ukrainians. See Maria Popova and Oxana Shevel, "What Doesn't Kill Ukraine," foreignpolicy.com (Argument blog), 12 March 2014, http://www.foreignpolicy.com/articles/2014/03/12/ what_doesn_t_kill_ukraine_why_kiev_could_emerge_stronger_from_crisis.

147. Arel, "Double-Talk."

148. Kulyk, "Language Identity,” 627, see also 630.

149. Pew Research Center, Ukrainians Want to Remain One Country, 4-6, 14, 16. For a passionately dissenting emphasis on the loyalty of Russian speakers, see Tanya Zaharchenko, “A Ukrainian Thesaurus in Russian,” ukraineanalysis, 17 March 2014, http://ukraineanalysis.wordpress.com/2014/05/17/a-ukrainian-thesaurus-in-russian/. 
150. Plokhy, Origins of the Slavic Nations, 11.

151. Tatiana Zhurzhenko, “'Capital of Despair': Holodomor Memory and Political Conflict in Kharkiv after the Orange Revolution," East European Politics and Societies 25, no. 3 (August 2011): 597-693.

152. Hryn, Hunger by Design.

153. Valery Soldatenko, head of the National Memory Institute appointed in 2010 by Yanukovych, as cited in "Communist Ukrainian Institute Head Denies Famine Was Deliberate,” Radio Free Europe/Radio Liberty, 29 July 2010, http://www.rferl.org/ content/Communist_Ukrainian_Institute_Head_Denies_Famine_Was_Deliberate/ 2112870.html.

154. Cf. Katchanovski, "Politics of Soviet and Nazi Genocides," esp. 995.

155. Zhurzhenko, "“Capital of Despair."”

156. Mykola Riabchuk, “Ukraine’s 'Muddling Through': National Identity and Postcommunist Transition," Communist and Post-Communist Studies 45, no. 3-4 (2012): 443.

157. Sergiu Gherghina and Lina Klymenko, "Why Look Back? Citizens' Attitudes toward the Communist Regime in Belarus, Russia, and Ukraine," Problems of Post-Communism 59, no. 1 (January-February 2012): 55-65.

158. KIIS, "Stavlennia ukraïntsiv do postati Iosifa Stalina," 10-20 June 2011 poll, posted on Oleksandr Tertychnyi's blog on 24 July 2011, "Stalin ochyma ukraïntsiv s'ohodni," http://w.politiko.ua/blogpost65887.

159. Pew Research Center, Ukrainians Want to Remain One Country, 14.

160. See, e.g.: Razumkov Centre, "Citizens Attitude towards Different Types of Territorial Organisation,” 21-25 December 2013 survey, http://www.uceps.org/ eng/news.php?news_id=451; KIIS, "The Views and Opinions of South-Eastern Regions Residents of Ukraine," April 2014 survey, http://www.kiis.com. ua/?lang=eng\&cat=news\&id=258; Pew Research Center, Ukrainians Want to Remain One Country, 8. Cf. also Adrian Karatnycky, "The Pushback in Ukraine," International New York Times, 24 May 2014.

161. Alina Inayeh, “Ukraine’s Sugar Rush and Europe's Bitterness," GMF Blog, 28 May 2014, http://blog.gmfus.org/2014/05/28/ukraines-sugar-rush-and-europes-bitterness/.

162. Edward Lucas, "Interview: Russia Watcher Lucas Says 'Tide Has Turned a Bit' for Ukraine," Radio Free Europe/Radio Liberty, 25 May 2014, http://www.rferl.org/ content/interview-edward-lucas-ukraine-election-turned-corner/25398089.html.

163. The Editorial Board, "No Thaw Yet in Ukraine," New York Times, 27 August 2014, A22.

164. Samuel Charap, “The Ukraine Impasse," Survival: Global Politics and Strategy 56, no. 5 (October-November 2014): 230.

165. Fyodor Lukyanov, "Sick and Tired of Ukraine," Russia in Global Affairs, 3 August 2012, http://eng.globalaffairs.ru/redcol/Sick-and-Tired-of-Ukraine-15625.

166. Fyodor Lukyanov, "The Form and Essence of the Eurasian Union," Russia in Global Affairs, 7 September 2012, http://eng.globalaffairs.ru/redcol/The-Form-and-theEssence-of-the-Eurasian-Union-15660. 
167. Timothy Snyder, "Ukraine's Promise of Peace Overtaken by Fresh Tragedy," FT.com, 19 February 2014, http://www.ft.com/cms/s/0/a4dc06d4-990c-11e3-a32f00144feab7de.html\#ixzz2toOOilkb.

168. Cited in "Armed Pro-Russian Separatists Storm Buildings in Eastern Ukraine," FT.com, 7 April 2014, http://www.ft.com/cms/s/0/4df09efe-be2b-11e3-961f00144feabdc0.html\#ixzz2yDtuYQ4h. Asked in December 2013, a majority of Ukrainians in all regions opposed a federal state. Razumkov Centre, "Citizens Attitude towards Different Types of Territorial Organisation," full text, p. 4 (percentage of population in favor of federalism: in the west, 11.7; center, 11.2; south, 18.4; east, 21.7).

169. See Jadwiga Ragoza, "Federation without Federalism: Relations between Moscow and the Regions," OSW Studies (Warsaw), no. 49 (April 2014), http://www.osw.waw. $\mathrm{pl} /$ sites/default/files/ang_prace_49_federacja_bez_net.pdf.

170. Sergei Lavrov, cited in "Putin's Cynical Plan to Split Ukraine," FT.com, 31 March 2014, http://www.ft.com/cms/s/0/0e827e9a-b8c2-11e3-835e-00144feabdc0. html\#ixzz2xeqqaZKT.

171. Kremlin aide Sergei Glazyev, referring in the first instance to the "eastern regions"; cited in "Russia's Lavrov: Ukraine Opposition Doesn't Deliver," cnbc.com, 22 February 2014, http://www.cnbc.com/id/101437265.

172. Dmitry Yefremenko, "Crossing Red Lines: Russia Takes the Lead in Revising the World Order," Russia in Global Affairs, 23 September 2014, http://eng.globalaffairs. ru/number/Crossing-Red-Lines-16989.

173. Valdai Discussion Club, The Crisis in Ukraine: Root Causes and Scenarios for the Future, ed. Pavel Andreev and Gayaneh Seiranyan, Valdai Discussion Club Report, Moscow, September 2014, 69, http://vid-1.rian.ru/ig/valdai/ukraine_eng.pdf.

174. See Tadeusz A. Olszanski, "Ukraine: Sovereign Decentralisation or Federalism without Sovereignty?” OSW Commentary (Warsaw), no. 134 (18 April 2014), http://www. osw.waw.pl/sites/default/files/commentary_134_0.pdf.

175. Alexey Arbatov, "Collapse of the World Order?" Russia in Global Affairs, 23 September 2014, http://eng.globalaffairs.ru/number/Collapse-of-the-World-Order-16987. For an example of the unabashed recourse to conservative-religious arguments, see Alexander Lukin, "What the Kremlin is Thinking: Putin's Vision for Eurasia," Foreign Affairs 93, no. 4 (July-August 2014): 85-93.

176. Arbatov, "Collapse of the World Order?"

177. John J. Mearsheimer, "Why the Ukraine Crisis is the West's Fault." Foreign Affairs 93, no. 5 (September-October 2014): 77-89; see the rejoinders by Michael McFaul and Stephen Sestanovich in "Faulty Powers," Foreign Affairs 93, no. 6 (NovemberDecember 2014): 167-178. In his response, Mearsheimer emphatically adopts the Kremlin designation of the Maidan revolution as a "coup."

178. Arbatov, "Collapse of the World Order?"

179. Oxana Shevel, "The Politics of Memory in a Divided Society: A Comparison of 
Post-Franco Spain and Post-Soviet Ukraine," Slavic Review 70, no. 1 (Spring 2011): 164.

180. Karl Marx, "The Eighteenth Brumaire of Louis Bonaparte," in The Marx-Engels Reader, ed. Robert Tucker (New York: Norton, 1972), 437. 
